Available online at GSC Online Press Directory

GSC Biological and Pharmaceutical Sciences

e-ISSN: 2581-3250, CODEN (USA): GBPSC2

Journal homepage: https://www.gsconlinepress.com/journals/gscbps

(SHORT COMMUNICATION)

\title{
Spectrophotometric method for dissolution analysis of pioglitazone from capsules
}

\author{
Patankar-Jain Kalpana $1^{*}$, Gadkari Parag ${ }^{2}$ and Pradhan Pushkar ${ }^{3}$ \\ ${ }^{1}$ Department of Chemistry, B. N. N. College, Bhiwandi, Thane, India. \\ ${ }^{2}$ Inventia Healthcare Pvt. Ltd., Thane, India. \\ ${ }^{3}$ Department of Chemistry, Ramnarain Ruia College, Mumbai, India.
}

Publication history: Received on 05 November 2018; revised on 28 November 2018; accepted on 08 December 2018

Article DOI: https://doi.org/10.30574/gscbps.2018.5.3.0131

\begin{abstract}
Pioglitazone, an anti-diabetic molecule have been analyzed from a marketed capsule consisting of glimepiride and pioglitazone using spectrophotometric method. The method was developed at $270 \mathrm{~nm}$ using $0.1 \mathrm{~N} \mathrm{HCl}$ as diluent. The method was found to be highly specific for pioglitazone in presence of glimepiride and other constituents of the capsule. The developed method is simple, precise, robust and stands validated as per ICH guidelines.
\end{abstract}

Keywords: Pioglitazone; Anti-diabetic; Spectrophotometer; Glimepiride

\section{Introduction}

Pioglitazone is a diabetes drug (thiazolidinedione-type, also called "glitazones") used along with a proper diet and exercise program to control high blood sugar in patients with type 2 diabetes. It works by helping to restore your body's proper response to insulin, thereby lowering your blood sugar.

Controlling high blood sugar helps prevent kidney damage, blindness, nerve problems, loss of limbs, and sexual function problems. Proper control of diabetes may also lessen your risk of a heart attack or stroke.

Pioglitazone is used either alone or in combination with other diabetes medications (such as metformin or a sulfonylurea such as glyburide).

\section{Material and methods}

\subsection{Chemicals}

Hydrochloric acid AR grade and Purified water were procured from Merck India Pvt Ltd.

\subsection{Standard solution preparations}

Weigh pioglitazone $\mathrm{HCl}$ equivalent to $30 \mathrm{mg}$ of pioglitazone in $1000 \mathrm{ml}$ volumetric flask. Add $300 \mathrm{ml}$ of methanol to the flask, sonicate, cool and make the content of the flask to $1000 \mathrm{ml}$ using $0.1 \mathrm{~N} \mathrm{HCl}$.

\subsection{Sample solution}

Weigh powdered pellets accurately equivalent to $30 \mathrm{mg}$ of pioglitazone in $1000 \mathrm{ml}$ volumetric flask. Add about $300 \mathrm{ml}$ of methanol, sonicate for 10 minutes. Add about $500 \mathrm{ml} 0.1 \mathrm{~N} \mathrm{HCl}$ and sonicate for about 20 minutes. Cool and make up

\footnotetext{
${ }^{*}$ Corresponding author

E-mail address: knjc00@gmail.com
} 
the volume with $0.1 \mathrm{~N} \mathrm{HCl}$. Filter the solution through $0.45 \mu$ membrane filter. Determine the absorbance of the standard and test solution at $270 \mathrm{~nm}$ using $0.1 \mathrm{~N} \mathrm{HCl}$ as blank.

\subsection{Dissolution conditions}

The dissolution was carried out in vitro.

Table 1 Dissolution parameters of the experiment

\begin{tabular}{ll}
\hline Parameter & Description \\
\hline Dissolution Apparatus & USP XXV Type II (paddle ) \\
RPM & 75 \\
Temperature & $37 \pm 0.5^{\circ} \mathrm{C}$ \\
Media Volume & $900 \mathrm{ml}$ \\
Dissolution Media & $\mathrm{N} \mathrm{HCl}$ \\
\hline
\end{tabular}

In each of the 6 vessels, place $900 \mathrm{ml}$ of dissolution medium and allow to equilibrate to $37^{\circ} \mathrm{C}$. Immerse the paddle, put weighed tablet in each of the jars \& start rotation at 75 RPM. At the end of the $30 \mathrm{~min}, 1,4$ and $8^{\text {th }}$ hour of rotation, withdraw with a pipette $10 \mathrm{ml}$ of solution. Replace the withdrawn solution with $10 \mathrm{ml}$ of dissolution medium. Dilute the aliquots of $30 \mathrm{~min}$ as $5 \mathrm{ml}$ to $10 \mathrm{ml}$ with diluting solvent \& filter through $0.45 \mu$ filter.

\subsection{Method validation}

\subsubsection{System Suitability}

System suitability tests were carried out to ensure reproducibility of the equipment. The test was carried out by measuring of standard solution in 5 replicates.

\subsubsection{Precision}

Precision is the measure of either the degree of reproducibility or of repeatability of the analytical method under normal conditions. The test were carried out with 6 assay samples in replicate of standard solutions.

\subsubsection{Linearity}

The linearity of an analytical procedure is its ability to obtain test results which are directly proportionally to the concentration of analyte in the sample.

Linearity of pioglitazone is carried out in the range $1.25 \mu \mathrm{g} / \mathrm{ml}$ to $7.5 \mu \mathrm{g} / \mathrm{ml}$.

\section{Results and discussion}

\subsection{System suitability}

The method was found to be suitable for the proposed analysis as the relative standard deviation of average peak area of system suitability test is not more than $2.0 \%$.

\subsection{Precision}

Precision measured at all level was within the acceptable criterion of NMT $6.0 \%$ indicating the efficiency of method for the proposed analysis.

\section{Conclusion}

The method developed for analysis of pioglitazone in presence of Glimepiride and other matrix stands to be validated as per ICH guidelines. The limits for all the parameters were met with no interference from the placebos of the capsules and hence this method can be used as quality control tool for analysis of the capsules. 


\section{Compliance with ethical standards}

\section{Disclosure of conflict of interest}

The authors, Patankar-Jain Kalpana, Gadkari Parag and Pradhan Pushkar, hereby declare that there is no conflict of interest whatsoever.

\section{References}

[1] Guideline IHT. (2005). Validation of analytical procedures: text and methodology Q2 (R1). In International Conference on Harmonization of Technical Requirements for the Registration of Pharmaceuticals for Human Use (ICH), Geneva, Switzerland, 11-12.

\section{How to cite this article}

Patankar-Jain K, Gadkari P, Pradhan P. (2018). Spectrophotometric method for dissolution analysis of pioglitazone from capsules. GSC Biological and Pharmaceutical Sciences, 5(3), 25-27. 